\title{
Coumarin or benzoxazinone bearing benzimidazolium and bis(benzimidazolium) salts; involvement in transfer hydrogenation of acetophenone derivatives and hCA inhibition
}

\author{
Mert Olgun Karataş,*, Serkan Dayan², Nilgün Kayacı², Ciğdem Bilen³, Emre Yavuz ${ }^{3}$, Nahit \\ Gencer $^{3}$, Bulent Alıcı', Nilgün Özpozan Kalaycıoğlu² and Oktay Arslan ${ }^{3}$ \\ ${ }^{1}$ Department of Chemistry, Faculty of Arts and Sciences, Inonu University, Road of Elazig $15^{\text {th }} \mathrm{km}$., \\ Malatya 44280, Turkey. \\ ${ }^{2}$ Department of Chemistry, Faculty of Science, Erciyes University, Neighborhood of Köşk, Kayseri 38039, \\ Turkey. \\ ${ }^{3}$ Department of Chemistry, Faculty of Art and Sciences, Balıkesir University, Cagis Campus, 10160 Balikesir \\ 10160, Turkey.
}

\begin{abstract}
Four new salts of benzimidazolium and bis(benzimidazolium) which include coumarin or benzoxazinone moieties were synthesized and the structures of the newly synthesized compounds were elucidated on the basis of spectral analyses such as ${ }^{1} \mathrm{H}-\mathrm{NMR},{ }^{13} \mathrm{C}-\mathrm{NMR}$, HSQC, IR, LC-MS and elemental analysis. Benzimidazolium salts were used intensively as $\mathrm{N}$-heterocyclic carbene (NHC) precursors in the various catalytic reactions such as transfer hydrogenation (TH), C-H bond activation, Heck, Suzuki reaction etc. With the prospect of potential NHC precursor properties of the synthesized compounds, they were employed in the (TH) reaction of $p$-substitute acetophenones (acetophenone, $p$-methyl acetophenone, $p$-chloro acetophenone) and good yields were observed. Coumarin compounds are known as inhibitor of carbonic anhydrase and inhibition effects of the synthesized compounds on human carbonic anhydrases (hCA) were investigated as in vitro. The in vitro results demonstrated that all compounds inhibited hCA I and hCA II activity. The inhibitory effects of the synthesized compounds on the hydratase and esterase activities of these isoenzymes (esterase activity is for hCA I) were studied in vitro. In relation to these activities, the inhibition equilibrium constants (Ki) were determined. The results showed that coumarin based benzimidazolium and bisbenzimidazolium salts are more active than benzoxazinones derivatives.
\end{abstract}

Keywords: Benzimidazolium; Benzoxazinone; Coumarin; Carbonic Anhydrase; Transfer Hydrogenation (TH).

\section{Introduction}

Benzimidazole is a bicyclic and heterocyclic compound which consists of the fusion of benzene and imidazole rings. One of the most well known benzimidazoles in nature is $N$-ribosyl dimethylbenzimidazole which serves as an axial ligand for cobalt in water soluble vitamin $\mathrm{B} 12^{1}$. Because of their synthetic utility, benzimidazole derivatives have been investigated as bioactive compounds. A number of benzimidazole derivatives were reported as, for example antihypertensive ${ }^{2}$, anti-inflammatory ${ }^{3}$, antimicrobial ${ }^{4}$, antiviral ${ }^{5}$, antioxidant $^{6}$, antitumor ${ }^{7}$, lipid modulator $^{8}$ and anticoagulant agents ${ }^{9}$.

In recent years, in addition to their biological properties, benzimidazole derivatives were also used as a carbon scaffold for the preparation of $\mathrm{N}$ heterocyclic carbene(NHC) complexes. ;A number of NHCs with different metal atoms were synthesized by the deprotonation of 1,3*corresponding author: Mert Olgun Karataş

E-mail address: mert.karatas@inonu.edu.tr dialkylbenzimidazolium salts ${ }^{10-12}$. Moreover, quite effective catalytic systems were employed in various useful catalytic reactions using 1,3dialkylbenzimidazolium salts and some metal salts in $\mathrm{situ}^{13-15}$. The hydrogenation of aldehydes or ketones to alcohols is an important reaction in organic synthesis. The $\mathrm{TH}$ reaction refers to the addition of a hydrogen molecule to another molecule from a source, such as alcohol, other than molecular hydrogen. When the $\mathrm{TH}$ is compared with conventional hydrogenation which uses molecular hydrogen, the experimental procedure of the $\mathrm{TH}$ reaction is safer and simpler than conventional hydrogenation ${ }^{16-18}$.

Coumarins belong to a class of compounds known as benzopyrones, some heterocyclic and bicyclic compounds which consist of the fusion of pyron and benzene rings. Some coumarin derivatives were used as anticoagulant and additives in food and cosmetics ${ }^{19,20}$. In addition various biological and pharmacological properties of 
coumarin derivatives were reported in the literature ${ }^{21,22}$ and most recently they were reported as inhibitors of the metalloenzyme carbonic anhydrase $(\mathrm{CA})^{23,24}$.

As an heterocyclic compound, benzoxazinone contains1,4-oxazinone ring fused to benzene which have been used extensively for building bioactive compounds. The anticancer ${ }^{25}$, antiulcer ${ }^{26}$, antihypertensive ${ }^{27}$, anti-inflammatory ${ }^{28}$ and other biological activities of 1,4-oxazinones and benzoxazines have been reported in the literature ${ }^{29-31}$. In addition to these reports, the anticonvulsant activities of some benzoxazinone derivatives were reported $^{32}$ and it is known that some anticonvulsant agents inhibit human CA izoenzymes effectively ${ }^{33}$.

The metalloenzyme CA catalyzes a simple but critically important physiological reaction: the involvement of the $\mathrm{CA}$ enzyme family, which catalyzes the physiological hydration of $\mathrm{CO}_{2}$ to yield bicarbonate and a proton, in many physiological/pathological processes open up widespread opportunities for the development of diverse specific inhibitors for clinical applications ${ }^{34-}$ 37. The active site of most CAs contains a zinc(II) ion $\left(\mathrm{Zn}^{2+}\right)$, which is essential for catalysis. The CA reaction involved in many physiological and pathological processes, including the respiration and transport of $\mathrm{CO}_{2}$ and bicarbonate between metabolizing tissues and the lungs, $\mathrm{pH}$ and $\mathrm{CO}_{2}$ homeostasis; electrolyte secretion in various tissues and organs, biosynthetic reactions such as gluconeogenesis, lipogenesis and ureagenesis, bone resorption, calcification and tumorigenicity ${ }^{38-46}$. Many of the CA isoenzymes involved in these processes are important therapeutic targets with the potential to be inhibited to treat a range of disorders including edema, glaucoma, obesity, cancer, epilepsy and osteoporosis. Given the physiological importance of the CA, the metabolic impact of chemicals for crop production should receive greater study $^{38,47}$.

The present study was carried out in order to synthesize, characterize and evaluate the catalytic and biological activities of benzimidazolium and bis(benzimidazolium) chlorides which contain coumarin or benzoxazinone moieties. Herein, our main aim is to synthesize more effective ligands (LHX) for $\mathrm{Ru}(\mathrm{II})$ metal in the $\mathrm{TH}$ reaction by combining coumarin and benzoxazinone with benzimidazolium and bisbenzimidazolium compounds. With the prospect of potential carbene properties of these functionalized salts they were employed as ligands in the $\mathrm{TH}$ reaction of acetophenone derivatives. The inhibitory effects of the newly synthesized compounds on the activities of purified human erythrocyte CA I and CA II isozymes were also investigated.

\section{Results and Discussion}

\section{Preparation and characterization of benzimidazolium and (bis)benzimidazolium salts}

As mentioned in the introduction, we focused on the synthesis of the functionalized benzimidazolium and bis(benzimidazolium) salts. For this purpose, we used biologically active coumarin and benzoxazinone groups. Firstly, we synthesized 4chloromethyl-6,8-dimethy-2H-chromen-2-one (1) using the procedure described by Frasinyuk ${ }^{48}$. Benzimidazolium salts (1a, 2a) were synthesized by the direct quaterniazation of Nalkylbenzimidazole in DMF. Bis(benzimidazolium) salts were synthesized by the reaction of $1,4-\operatorname{di}(1 \mathrm{H}$ benzo[d]imidazol-1-yl)butane with 1 or 6(chloroacetyl)-2H-1,4-benzoxazine-3(4H)-one $\mathbf{2}$ in DMF (1/2 molar ratio, respectively). The reaction conditions for the synthesis of the four compounds were given in Scheme 1. All of the four salts are air and moisture stable in the solid state as well as in solution and they were isolated in good yields and fully characterized by ${ }^{1} \mathrm{H}-\mathrm{NMR},{ }^{13} \mathrm{C}-\mathrm{NMR}$, IR, LCMS spectroscopy and elemental analyses. We could not achieve a single crystal for any of the four compounds despite all efforts. Therefore, for further characterization of the bis(benzimidazolium) salts $(\mathbf{1 b}, \mathbf{2 b})$, they were evaluated by the HSQC NMR technique. HSQC spectra were evaluated on 600 $\mathrm{MHz}$ NMR spectrometer to avoid problems may arise due to resolution and the spectrum of $\mathbf{1 b}$ is given in Figure 1. The ${ }^{13} \mathrm{C}-\mathrm{NMR}$ chemical shifts were consistent with the proposed structure, the imino carbon $(\mathrm{NCHN})$ appeared as a typical singlet in the ${ }^{1} \mathrm{H}$-decoupled mode at 142.7, 142.7, 144.1 and $144.0 \mathrm{ppm}$, respectively for benzimidazolium and bis(benzmidazolium) chlorides $\mathbf{1 a}, \mathbf{2 a}, \mathbf{1 b}$ and $\mathbf{2 b}$. These values are in good agreement with the previously reported results ${ }^{13,15}$. The ${ }^{1} \mathrm{H}-\mathrm{NMR}$ data show that the acidic $-\mathrm{NCHN}$ - protons of the benzimidazolium salts (1a,2a, 9.28 and 8.99, respectively) are less downfield shielded than the bis(benzimidazolium) salts (1b,2b, 10.43 and 10.11, respectively) which indicates a considerable difference in the acidity of these protons in agreement with the literature ${ }^{13,15}$. In the structures of the coumarin bearing salts $\mathbf{1 a}$ and $\mathbf{1 b}$, olefinic protons are important for characterization and their signals were observed were ranged from 5.91 to 5.99 ppm in ${ }^{1} \mathrm{H}-\mathrm{NMR}$, olefinic carbons were observed in the scale of 112.2 and $112.7 \mathrm{ppm}$ in ${ }^{13} \mathrm{C}-\mathrm{NMR}$ as a singlet for $\mathbf{1 a}$ and $\mathbf{1 b}$, respectively. For benzoxazinone bearing salts $\mathbf{2 a}$ and $\mathbf{2 b}$, free $-\mathrm{N}-\mathrm{H}$ protons were located in the range of 11.09 and 11.17 ppm, respectively. IR spectra and elemental analysis also matched the structures of compounds $\mathbf{1 a - 2} \mathbf{b}$. 


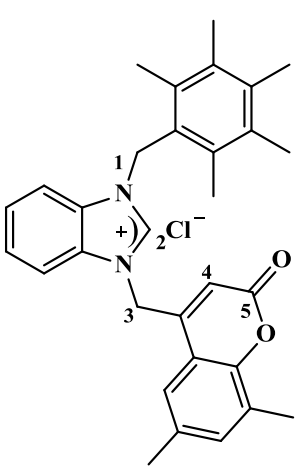

$1 a$

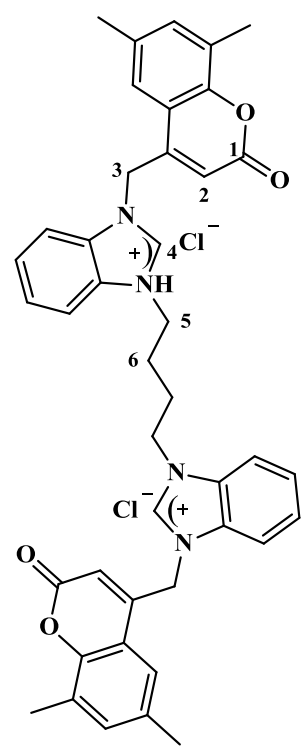

2a

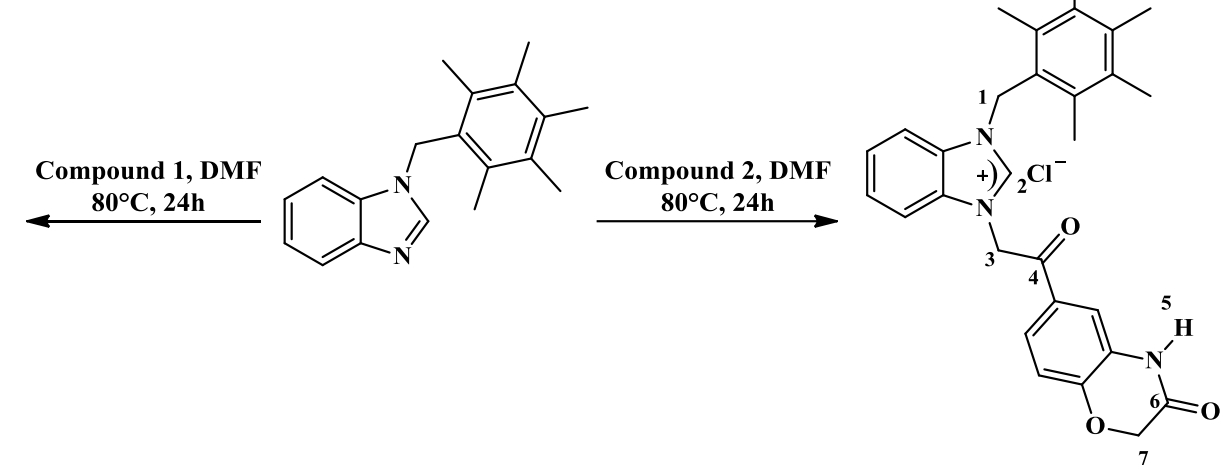

2a
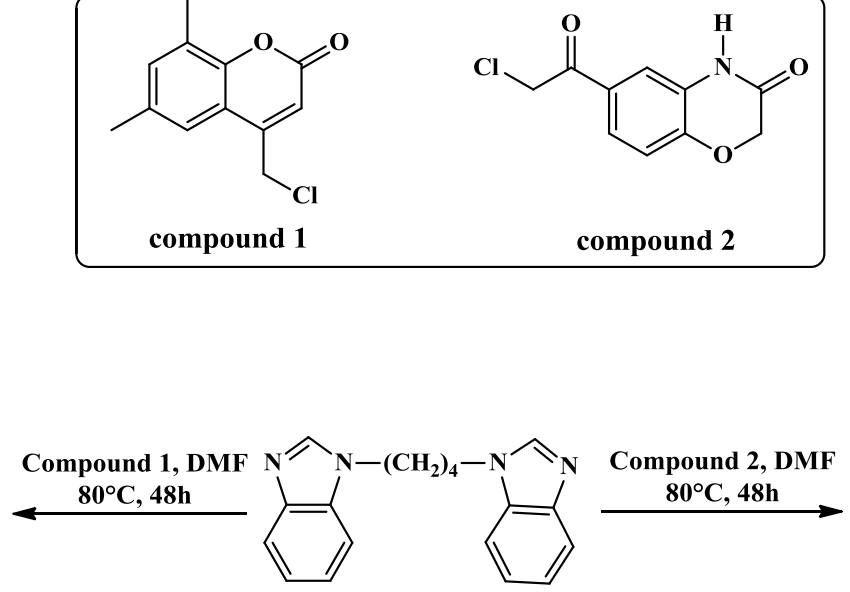

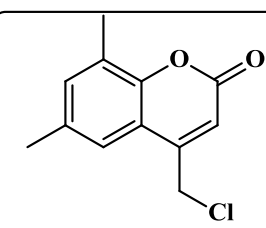

compound 1

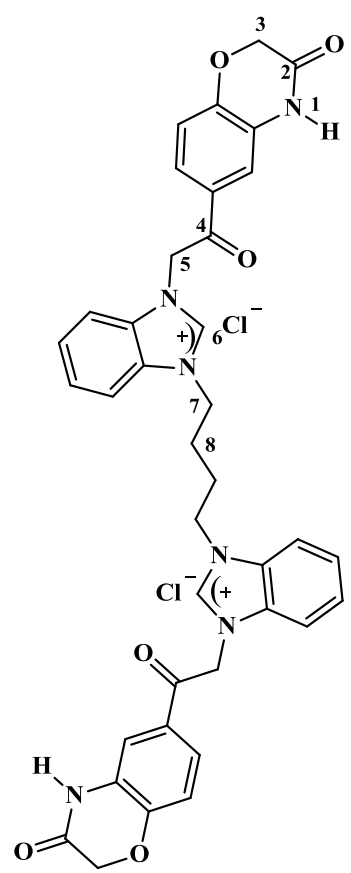

2b

Scheme 1. Synthesis of benzimidazolium and bis(benzimidazolium) salts $\mathbf{1}$ a,b and $\mathbf{2}$ a,b

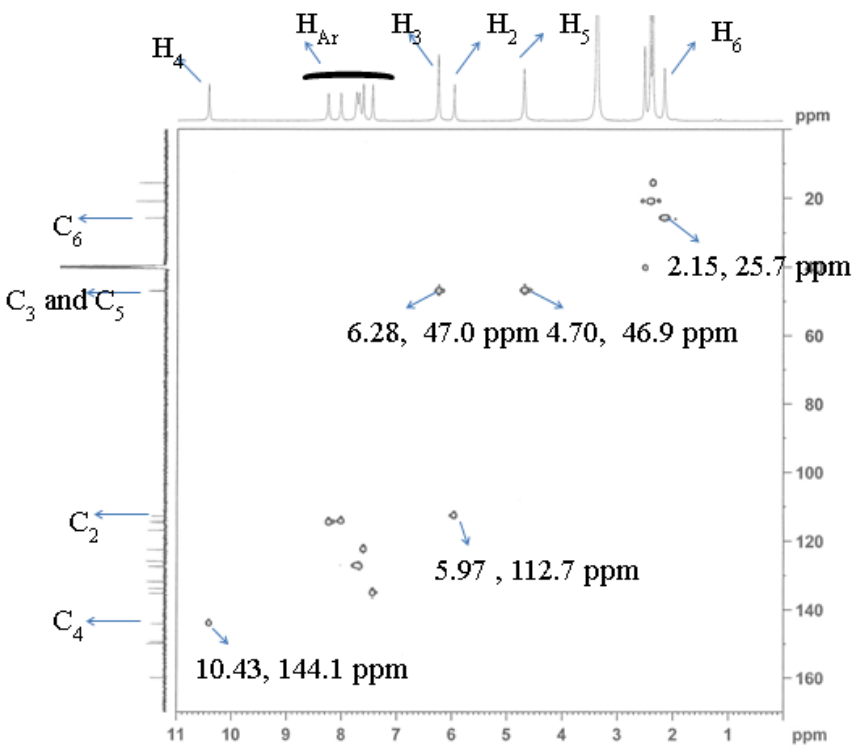

Figure 1. HSQC spectrum of compound 1b 


\section{Catalytic Hydrogen Transfer Reaction}

Catalytic studies with $\mathbf{1 a - 2 b}$ (LHX) were performed for the $\mathrm{TH}$ of acetophenone to give 1-phenylethanol in the presence of base with 2propanol as a hydrogen source (Scheme 2). The reaction conditions for this important process are economic, relatively mild and environmentally friendly. The volatile acetone product can also be easily removed to shift an unfavorable equilibrium.

The acetophenone was kept as a test substrate and was allowed to react in 2-propanol with catalytic quantities of Ru/LHX in the presence of different<smiles>[R]c1ccc(C(C)O)cc1</smiles>

Scheme 2. Hydrogen transfer of some $p$-substitute acetophenone derivatives by $\left[(p \text {-cymene }) \mathrm{RuCl}_{2}\right]_{2} / \mathrm{LHX}$ catalyst system.

Table 1. Catalytic activity for transfer hydrogenation of acetophenone catalyzed by Ru(II)/LHX catalyst system with different bases.

\begin{tabular}{|c|c|c|c|c|}
\hline Entry & Ru(II)/LHX & Base & Yield $(\%)^{\mathbf{a}}$ & TOF $\left(h^{-1}\right)^{b}$ \\
\hline 1 & (1a) & \multirow{6}{*}{ КОН } & $17.2^{\mathrm{c}}, 22.0^{\mathrm{d}}, 32.1^{\mathrm{e}}, 48.4^{\mathrm{f}}, 63.8^{\mathrm{g}}$ & 516 \\
\hline 2 & (2a) & & $15.0^{\mathrm{c}}, 18.4^{\mathrm{d}}, 28.1^{\mathrm{e}}, 45.7^{\mathrm{f}}, 61.2^{\mathrm{g}}$ & 450 \\
\hline 3 & (1b) & & $15.1^{\mathrm{c}}, 20.3^{\mathrm{d}}, 30.2^{\mathrm{e}}, 49.0^{\mathrm{f}}, 64.9^{\mathrm{g}}$ & 453 \\
\hline 4 & (2b) & & $19.2^{\mathrm{c}}, 25.0^{\mathrm{d}}, 34.5^{\mathrm{e}}, 49.7^{\mathrm{f}}, 69.1^{\mathrm{g}}$ & 576 \\
\hline 5 & - & & $14.0^{c}, 17.8^{d}, 27.3^{e}, 45.0^{f}, 59.4^{g}$ & 420 \\
\hline 6 & Only KOH & & $\mathbf{9}^{\mathrm{e}}, \mathbf{1 4 ^ { \mathrm { f } }}$ & 78 \\
\hline 7 & (1a) & \multirow{4}{*}{$\mathrm{NaOH}$} & $7.5^{\mathrm{c}}, 12.4^{\mathrm{d}}, 20.6^{\mathrm{e}}, 26.3^{\mathrm{f}}, 30.2^{\mathrm{g}}$ & $225^{c}$ \\
\hline 8 & (2a) & & $8.2^{\mathrm{c}}, 13.6^{\mathrm{d}}, 22.5^{\mathrm{e}}, 27.9^{\mathrm{f}}, 32.5^{\mathrm{g}}$ & $246^{c}$ \\
\hline 9 & (1b) & & $8.9^{\mathrm{c}}, 15.1^{\mathrm{d}}, 22.8^{\mathrm{e}}, 28.2^{\mathrm{f}}, 33.1^{\mathrm{g}}$ & $267^{\mathrm{c}}$ \\
\hline 10 & (2b) & & $10.1^{\mathrm{c}}, 17.6^{\mathrm{d}}, 25.6^{\mathrm{e}}, 28.4^{\mathrm{f}}, 35.5^{\mathrm{g}}$ & $\mathbf{3 0 3}^{\mathrm{c}}$ \\
\hline 11 & (1a) & \multirow{4}{*}{$\mathbf{E t}_{3} \mathbf{N}$} & $<5$ & n.c. \\
\hline 12 & (2a) & & $<5$ & n.c. \\
\hline 13 & (1b) & & $<5$ & n.c. \\
\hline 14 & (2b) & & $<5$ & n.c. \\
\hline 15 & (1a) & \multirow{4}{*}{ KOBut } & $5.2^{\mathrm{c}}, 9.3^{\mathrm{d}}, 13.5^{\mathrm{e}}, 19.1^{\mathrm{f}}, 22.4^{\mathrm{g}}$ & $156^{\mathrm{c}}$ \\
\hline 16 & (2a) & & $5.1^{\mathrm{c}}, 10.0^{\mathrm{d}}, 15.1^{\mathrm{e}}, 21.0^{\mathrm{f}}, 25.3^{\mathrm{g}}$ & $153^{\mathrm{c}}$ \\
\hline 17 & (1b) & & $5.0^{\mathrm{c}}, 9.7^{\mathrm{d}}, 14.5^{\mathrm{e}}, 20.2^{\mathrm{f}}, 24.7^{\mathrm{g}}$ & $150^{c}$ \\
\hline 18 & (2b) & & $5.2^{\mathrm{c}}, 10.9^{\mathrm{d}}, 18.1^{\mathrm{e}}, 23.2^{\mathrm{f}}, 27.1^{\mathrm{g}}$ & $156^{c}$ \\
\hline 19 & (2b) & $\begin{array}{l}\text { KOH } \\
(1 \mathrm{mmol})\end{array}$ & $31^{\mathrm{e}}$ & $155^{\mathrm{e}}$ \\
\hline 20 & (2b) & $\begin{array}{l}\text { KOH } \\
(\mathbf{0 . 1 m m o l})\end{array}$ & $17^{\mathrm{e}}$ & $85^{\mathrm{e}}$ \\
\hline 21 & (2b) & $\begin{array}{l}\text { Absence of } \\
\text { base }\end{array}$ & $<5^{\text {f }}$ & n.c. \\
\hline
\end{tabular}

Reaction conditions: $10.0 \mathrm{mmol}$ acetophenone, $5 \mathrm{mmol} \mathrm{KOH}, 0.02 \mathrm{mmol} \mathrm{Ru}(\mathrm{II}) / \mathrm{LHX}, 2$-propanol (6 mL);

Temperature $80^{\circ} \mathrm{C}$. S/C (500/1).

${ }^{a} \mathrm{GC}$ yields, yields are based on phenylethanol,

b $\mathrm{TOF}=$ moles of product / (moles of the catalyst)x(hour),

n.c.: not calculated.

c $10 \mathrm{~min}$. , $^{\text {d }} 30 \mathrm{~min}$. , $^{\text {e }} 60 \mathrm{~min} .{ }^{\text {f }} 120 \mathrm{~min}$. , $^{\text {g }} 180 \mathrm{~min}$.

Under these conditions $p$-chloroacetophenone reacts very well and in good yields with 2-propanol (Figure 2). The presence of electron withdrawing substituent $(\mathrm{Cl})$ on acetophenone has a significant effect on the reduction of $p$-substitute acetophenone bases like $\mathrm{KOH}, \mathrm{NaOH}, \mathrm{Et}_{3} \mathrm{~N}$ (as organic base) and $\mathrm{KO}^{\mathrm{t}} \mathrm{Bu}$. It has been observed that $\mathrm{NaOH}$ and $\mathrm{KOH}$ have good conversion when compared to $\mathrm{Et}_{3} \mathrm{~N}$ and $\mathrm{KOBu}^{\mathrm{t}}$ in $\mathrm{TH}$ reactions. According to the high rate of conversion, the bases are classified : $\mathrm{KOH}>$ $\mathrm{NaOH}>\mathrm{KO}^{t} \mathrm{Bu}>\mathrm{Et}_{3} \mathrm{~N}$. As in previous studies, the best results were obtained with $\mathrm{KOH}^{18}$ (Table 1).

Thus, the catalytic experiments were carried out using $10 \mathrm{mmol}$ of acetophenone derivatives, 0.01 mmol of $\left[(p \text {-cymene }) \mathrm{RuCl}_{2}\right]_{2}, 0.02 \mathrm{mmol}$ of LHX, 5 mmol of $\mathrm{KOH}$, and $10 \mathrm{~mL}$ of 2-propanol, with a catalyst-base-substrate ratio of $0.02: 1: 10$. 
All the experiments were carried out in an air atmosphere. This indicates that air is not involved in the $\mathrm{TH}$ process and the $\left[(p \text {-cymene }) \mathrm{RuCl}_{2}\right]_{2} / \mathrm{LHX}$ catalyst systems are air-stable.

a)

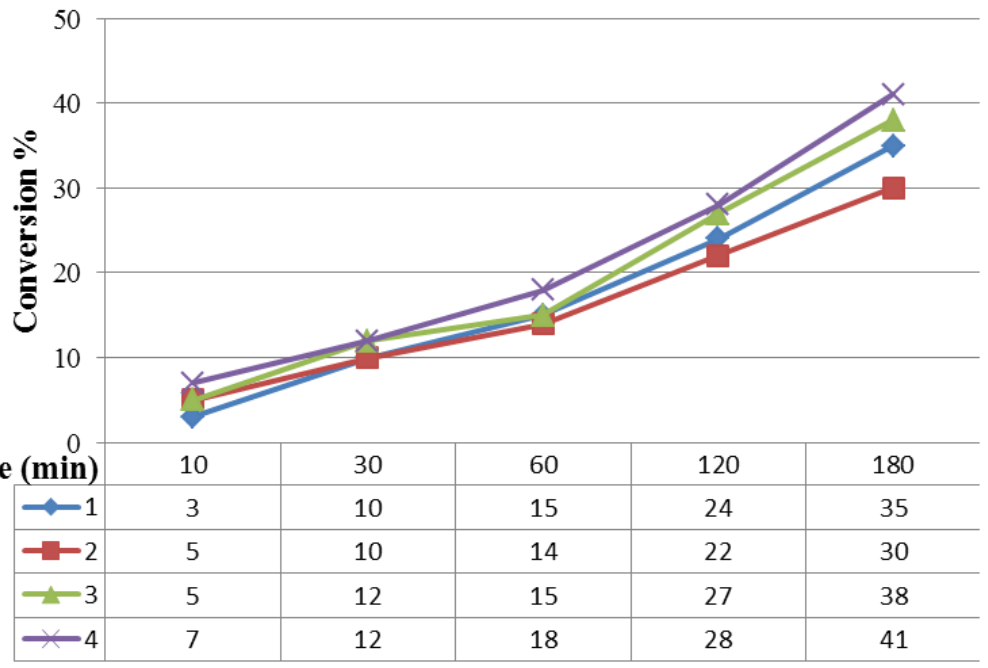

b)

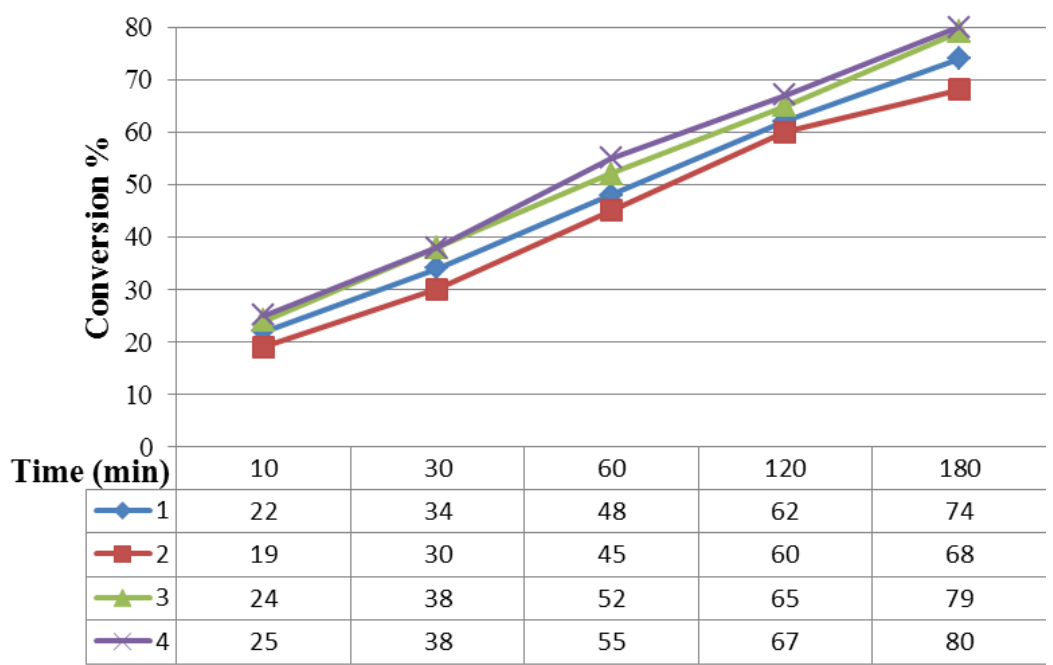

Figure 2. Catalytic activity for the transfer hydrogenation of acetophenone for (1a) appear as blue, $\mathbf{\square}$ for (2a) appear as red, $\boldsymbol{\Delta}$ for (1b) appear as green, $\mathbf{x}$ for (2b) appear as purple.

(a) In the presence of 2-propanol at $80{ }^{\circ} \mathrm{C}$ with $\left[(p \text {-cymene }) \mathrm{RuCl}_{2}\right]_{2} / \mathrm{LHX}$; methylacetophenone/Ru/KOH, 10:0.02:1

(b) In the presence of 2-propanol at $80{ }^{\circ} \mathrm{C}$ with $\left[(p \text {-cymene }) \mathrm{RuCl}_{2}\right]_{2} / \mathrm{LHX}$;4-chloroacetophenone/Ru/KOH, 10:0.02:1

\section{CA Inhibition}

The recently reported class of effective CAIs, coumarins and thiocoumarins, have an inhibition mechanism not dependent on $\mathrm{Zn}(\mathrm{II})$, and bind (in hydrolyzed form) to the same active site region as the activators, occluding the entrance to the active site while the other three CAI groups bind to the Zinc (II) ion or Zinc coordinated water molecule/hyroxide ion. Crystallographic studies showed that the natural coumarin compound, namely 6-(1S-hydroxy-3-methylbutyl)-7-methoxy-2H-

chromen-2-one, was hydrolyzed within the CA active site with the formation of 2-hydroxycinnamic acids, which have significant CA inhibitory properties and bind in a completely unprecedented manner to the enzyme, not interacting with the $\mathrm{Zn}$ (II) ion $^{23}$.

To evaluate the CA inhibitory activity, all of the compounds were subjected to $\mathrm{CA}$ inhibition assay with $\mathrm{CO}_{2}$ as substrate. The results demonstrated that all compounds inhibited hCA I and II enzyme activity. The inhibition values of $\mathbf{1 - 2 b}$ against CAs are summarized in Table 2 . We determined $\mathrm{IC}_{50}$ values ranging between 5.55-19.98 $\mu \mathrm{M}$ for hCA I and $6.06-25.23 \mu \mathrm{M}$ for hCA II and $\mathrm{Ki}$ values for hCA I esterase activity were ranged between 55.23$252.21 \mu \mathrm{M}$. Esterase activity experiments showed that inhibition type of these compounds is noncompetative. Among them, $\mathbf{1 a}$ and $\mathbf{1 b}$ was found to be the most active. From this study, some fundings emerged and the quaternization of coumarin and benzoxazinone compounds with benzimidazole or 
bis(benzimidazole) increased the inhibitory activity. When the activities of the synthesized compounds were compared, the coumarin bearing salts were found to be more active than the benzoxazinone bearing salts, especially for hCA II $(\mathbf{1 b}>\mathbf{1 a}>\mathbf{2 a}>$ 2b).

Most recently Korkmaz and co-workers reported the synthesis of thiourea containing benzimidazole moieties and they tested three derivatives of these compounds as inhibitors of hCA I and hCA $\mathrm{II}^{49}$. Their $\mathrm{K}_{\mathrm{i}}$ values were ranged between 46.1-73.6 $\mu \mathrm{M}$ for hCA I. In this study, compounds $1 \mathrm{a}, 1 \mathrm{~b}$ and $2 \mathrm{a}$ showed close inhibitory activity when compared benzimidazole-thioure hybrid compounds.

Table 2. The $\mathrm{IC}_{50}$ and $\mathrm{Ki}$ values of compounds (hCA, human carbonic anhydrase)

\begin{tabular}{ccccc}
\hline Compound & $\begin{array}{c}\text { hCA I Hydratase } \\
\text { activity IC50 }(\mu \mathbf{M})\end{array}$ & $\begin{array}{c}\text { hCA II Hydratase } \\
\text { activity IC50 }(\mu \mathbf{M})\end{array}$ & $\begin{array}{c}\text { hCA I Esterase } \\
\text { activity } \mathbf{K}_{\mathbf{i}}(\boldsymbol{\mu M})\end{array}$ & Inhibition type \\
\hline 1 & 10.04 & 14.24 & 252.21 & Non-competative \\
2 & 19.98 & 25.23 & 167.82 & Non-competative \\
$1 \mathrm{a}$ & 6.14 & 6.66 & 55.23 & Non-competative \\
$1 \mathrm{~b}$ & 5.55 & 6.06 & 61.33 & Non-competative \\
$2 \mathrm{a}$ & 6.59 & 21.07 & 87.41 & Non-competative \\
$2 \mathrm{~b}$ & 11.20 & 23.04 & 171.71 & Non-competative \\
\hline
\end{tabular}

\section{Conclusion}

In conclusion, we have reported the synthesis and characterization of novel functionalized benzimidazolium and bis(benzimidazolium) salts. These compounds are hybrid substrates which include benzimidazolium as a NHC precursor and coumarin as a CA inhibitor. It is known that a mixture of azolium salts and $\left[(p \text {-cymene }) \mathrm{RuCl}_{2}\right]_{2}$ has been used as a precatalyst for the $\mathrm{TH}$ reaction. One of the main aims was to investigate the effects of coumarin and benzoxazinone groups as ligands in the $\mathrm{TH}$ reaction. Thus, the catalytic activities of the synthesized salts were investigated in the $\mathrm{TH}$ reaction and good yields were obtained. With the prospect of potential CA inhibitory properties of the synthesized compounds, they were investigated as $\mathrm{CA}$ inhibitors and the results showed that all of the synthesized compounds inhibited hCA I and hCA II enzyme activity. The contribution of benzimidazolium salts to CA inhibitory activity was investigated. Besides coumarin bearing salts (1a,b), benzoxazinone bearing salts $(\mathbf{2 a}, \mathbf{b})$ inhibited hCA I and hCA II effectively. Our results suggest that these newly synthesized compounds are likely to be adopted as candidates to treat glaucoma and epilepsy.

\section{Experimental Section}

For the preparation of benzimidazolium and bisbenzimidazolium salts, all reactions were carried out in standard Schlenk type flasks. Chemicals and solvents were purchased from Sigma Aldrich, Merck. 6-(chloroacetyl)-2H-1,4-benzoxazine-3(4H)one was supplied commercially, controlled by ${ }^{1} \mathrm{H}-$ NMR and used without further purification. Melting points were determined by Electrothermal-9200 melting point apparatus. The FT-IR spectra were recorded on an ATR unit in the range of
400-4000 $\mathrm{cm}^{-1}$ with a Perkin Elmer Spectrum 100 Spectrophotometer. The ${ }^{1} \mathrm{H}-\mathrm{NMR}$ and ${ }^{13} \mathrm{C}-\mathrm{NMR}$ spectra were recorded using a Bruker FT spectrometer operating at $300.13 \mathrm{MHz}\left({ }^{1} \mathrm{H}\right), 75.47$ $\mathrm{MHz}\left({ }^{13} \mathrm{C}\right)$ and HSQC spectra were recorded using Bruker 600 Avance $3 \mathrm{HD}$ spetrometer operating at $600.134 \mathrm{MHz}\left({ }^{1} \mathrm{H}\right)$ and $150.918 \mathrm{MHz} \quad\left({ }^{13} \mathrm{C}\right)$. Chemical shifts are given in ppm relative to TMS. Elemental analyses were performed by a LECO CHNS-932 elemental analyzer at IBTAM (Inonu University Scientific and Technological Research Center). LC-MS spectra were performed on an Agilent 1100 LC/MSD SL mass spectrometer equipped with an electrospray ion source.

\section{Synthesis and characterization of compounds Synthesis of 1-(2,3,4,5,6-pentamethyl- benzyl)benzimidazol and 1,4-di(1H- benzo[d]imidazol-1-yl)butane. 1-(2,3,4,5,6- pentamethylbenzyl)benzimidazol and 1,4-di(1H- benzo[d]imidazol-1-yl)butane were synthesized by the procedure described in the literature ${ }^{50}$.}

Synthesis of benzimidazolium salts (1a and 2a) (General Method). 4-chloromethyl-6,8-dimethyl$2 \mathrm{H}$-chromen-2-one (compound 1) was synthesized by the procedure described by Frasinyuk (m.p.:146 ${ }^{\circ} \mathrm{C}$ ref. no 48 143-145 $\left.{ }^{\circ} \mathrm{C}\right) . \quad 1-(2,3,4,5,6-$ pentamethylbenzyl)benzimidazol (1.4 g, $5 \mathrm{mmol})$ was dissolved in $5 \mathrm{~mL}$ DMF. Five millimoles of 4chloromethyl-6,8-dimethyl-2 $H$-chromen-2-one (1.12 g) (1) or 6-chloroacetyl-2H-1,4-benzoxazine-3(4H)one $(1.13 \mathrm{~g})(2)$ was added to this solution and the resulting mixture was heated for 24 hours at $80{ }^{\circ} \mathrm{C}$. Later, the mixture was cooled to ambient temperature. Twenty milliliters of diethyl ether was added and the precipitates were collected by filtration. The crude product was washed with hexane $(2 \times 10 \mathrm{~mL})$ and diethyl ether $(10 \mathrm{~mL})$, then dried under reduced pressure. 
1-(2,3,4,5,6-pentamethylbenzyl)-3-((6,8-

dimethyl-2H-chromen-2-one-4-

yl)methyl)benzimidazolium chloride (1a). Yield 2,3 g, 92\%, white solid, mp $257{ }^{\circ} \mathrm{C}$. IR spectrum, $\mathrm{v}, \mathrm{cm}^{-1}: 1731(\mathrm{CO}) ; 1631(\mathrm{C}=\mathrm{C}) ; 1590(\mathrm{C}=\mathrm{C}) . \quad{ }^{1} \mathrm{H}-$ NMR (300 MHz, DMSO-d $\left.)_{6}\right), \delta, p p m ; 9.28(s, 1 \mathrm{H}$, $\left.\mathrm{H}_{2}\right) ; 8.34-7.44\left(\mathrm{~m}, 6 \mathrm{H}, \mathrm{H}_{\mathrm{Ar}}\right) ; 6.10\left(\mathrm{~s}, 2 \mathrm{H}, \mathrm{H}_{3}\right) ; 5.91(\mathrm{~s}$, $\left.1 \mathrm{H}, \mathrm{H}_{4}\right) ; 5.78\left(\mathrm{~s}, 2 \mathrm{H}, \mathrm{H}_{1}\right) ; 2.38\left(\mathrm{~s}, 3 \mathrm{H}, \mathrm{H}_{\mathrm{CH} 3}\right) ; 2.36(\mathrm{~s}$, $\left.3 \mathrm{H}, \mathrm{H}_{\mathrm{CH} 3}\right) ; 2.26\left(\mathrm{~s}, 3 \mathrm{H}, \mathrm{H}_{\mathrm{CH} 3}\right) ; 2.24\left(\mathrm{~s}, 6 \mathrm{H}, \mathrm{H}_{\mathrm{CH} 3}\right)$; $2.23\left(\mathrm{~s}, 6 \mathrm{H}, \mathrm{H}_{\mathrm{CH} 3}\right) .{ }^{13} \mathrm{C}-\mathrm{NMR}\left(75 \mathrm{MHz}, \mathrm{DMSO}-\mathrm{d}_{6}\right)$, $\delta$, ppm: $159.9\left(-\mathrm{C}_{5}\right) ; 149.8 ; 149.7 ; 142.7\left(-\mathrm{C}_{2}\right) ; 136.8$; $135.1 ; 134.4 ; 133.8 ; 133.5 ; 132.3 ; 132.2 ; 127.8$; $127.4 ; 126.1 ; 125.9 ; 122.4 ; 116.8 ; 114.7 ; 114.4$ $112.2\left(-\mathrm{C}_{4}\right) ; 47.3\left(-\mathrm{C}_{3}\right) ; 47.1\left(-\mathrm{C}_{1}\right) ; 20.8 ; 17.5 ; 17.2$; 16.9; 15.6. Found, \%: C 74.41; H 6.53; N 5.66. $\mathrm{C}_{31} \mathrm{H}_{33} \mathrm{ClO}_{2} \mathrm{~N}_{2}$. Calculated, \%: C 74.31; H 6.64; N 5.59.

1-(2,3,4,5,6-pentamethylbenzyl)-3-(6-acetyl2H-1,4-benzoxazine-3(4H)-one)benzimidazolium chloride (2a). Yield $2.06 \mathrm{~g}, 86 \%$, white solid, mp $210{ }^{\circ} \mathrm{C}$. IR spectrum, $v, \mathrm{~cm}^{-1}: 3426(\mathrm{NH}) ; 1692(\mathrm{CO})$; 1679(O); 1598(C=N). ${ }^{1} \mathrm{H}-\mathrm{NMR}(300 \mathrm{MHz}, \mathrm{DMSO}-$ $\left.\mathrm{d}_{6}\right), \delta, \mathrm{ppm} ; 11.10\left(\mathrm{~s}, 1 \mathrm{H}, \mathrm{H}_{5}\right) ; 8.99\left(\mathrm{~s}, 1 \mathrm{H}, \mathrm{H}_{2}\right) ; 8.31$ 7.15(s, 7H, $\left.\mathrm{H}_{\mathrm{Ar}}\right) ; 6.21\left(\mathrm{~s}, 2 \mathrm{H}, \mathrm{H}_{3}\right) ; 5.81\left(\mathrm{~s}, 2 \mathrm{H}, \mathrm{H}_{1}\right)$; $4.74\left(\mathrm{~s}, 2 \mathrm{H}, \mathrm{H}_{7}\right) ; 2.25\left(\mathrm{~s}, 3 \mathrm{H}, \mathrm{H}_{\mathrm{CH} 3}\right) ; 2.22(\mathrm{~s}, 12 \mathrm{H}$, $\left.\mathrm{H}_{\mathrm{CH} 3}\right) .{ }^{13} \mathrm{C}-\mathrm{NMR}\left(75 \mathrm{MHz}, \mathrm{DMSO}-\mathrm{d}_{6}\right), \delta$, ppm: $190.1\left(-\mathrm{C}_{4}\right) ; 164.4\left(-\mathrm{C}_{6}\right) ; 148.6 ; 142.7\left(-\mathrm{C}_{2}\right) ; 136.9$; $134.3 ; 133.5 ; 132.8 ; 131.5 ; 128.5 ; 128.0 ; 127.5$; $127.1 ; 126.0 ; 125.1 ; 116.8 ; 115.7 ; 114.4 ; 67.2\left(-\mathrm{C}_{7}\right)$; $53.3\left(-\mathrm{C}_{3}\right) ; 46.9\left(-\mathrm{C}_{1}\right) ; 17.5 ; 17.2 ; 16.8$. Found, \%: C 69.33; H 6.19; N 8.51. $\mathrm{C}_{29} \mathrm{H}_{30} \mathrm{ClO}_{3} \mathrm{~N}_{3}$. Calculated, $\%$ : C 69.11; H 6.00; N 8.34,

Synthesis of bis(benzimidazolium) salts (1b and 2b) (General Method). 1,4-di(1Hbenzo[d]imidazol-1-yl)butane $(0.87 \mathrm{~g}, 3 \mathrm{mmol})$ was dissolved in $5 \mathrm{~mL}$ DMF. Six millimoles of 4-chloromethyl-6,8-dimethyl-2H-chromen-2-one $(1.34 \mathrm{~g})(\mathbf{1})$ or 6 -chloroacetyl-2 $H$-1,4-benzoxazine$3(4 H)$-one $(1.36 \mathrm{~g})(\mathbf{2})$ was added to this solution and the resulting mixture was heated for 48 hours at 90 ${ }^{\circ} \mathrm{C}$. After this period, the mixture was cooled to ambient temperature. Twenty milliliters of diethyl ether was added and the precipitates were collected by filtration. The crude product was washed with hexane $(2 \times 10 \mathrm{~mL})$ and acetone $(10 \mathrm{~mL})$ then dried under reduced pressure.

1,4-Bis(1-((6,8-dimethyl-2H-chromen-2-one-4yl)methyl)benzimidazolium-3-yl)butane

dichloride (1b). Yield 1,4 g, 64\%, white solid, mp $222^{\circ} \mathrm{C}$; IR spectrum $v, \mathrm{~cm}^{-1}: 1717(\mathrm{CO}) ; 1589(\mathrm{C}=\mathrm{N})$. ${ }^{1} \mathrm{H}-\mathrm{NMR}(600 \mathrm{MHz}$, DMSO-d 6 ), $\delta, \mathrm{ppm:} 10.43$ $\left(\mathrm{s}, 1 \mathrm{H}, \mathrm{H}_{4}\right) ; 8.26-7.45\left(\mathrm{~m}, 6 \mathrm{H}, \mathrm{H}_{\mathrm{Ar}}\right) ; 6.28\left(\mathrm{~s}, 2 \mathrm{H}, \mathrm{H}_{3}\right)$; 5.97(s, $\left.1 \mathrm{H}, \mathrm{H}_{2}\right) ; 4.70\left(\mathrm{~s}, 2 \mathrm{H}, \mathrm{H}_{5}\right) ; 2.51\left(\mathrm{~s}, 3 \mathrm{H}, \mathrm{H}_{\mathrm{CH} 3}\right)$; $2.41\left(\mathrm{~s}, 3 \mathrm{H}, \mathrm{H}_{\mathrm{CH} 3}\right) ; 2.15\left(\mathrm{~s}, 2 \mathrm{H}, \mathrm{H}_{6}\right) .{ }^{13} \mathrm{C}-\mathrm{NMR}(150$ MHz, DMSO-d 6 ), $\delta$, ppm: 159.9(-- 1 ); 149.9; 149.4; $144.1\left(-\mathrm{C}_{4}\right) ; 135.2 ; 133.8 ; 131.9 ; 131.7 ; 127.5 ; 127.3$; $125.8 ; 122.5 ; 116.8 ; 114.6 ; 114.2 ; 112.7\left(-\mathrm{C}_{2}\right) ; 47.0$ $\left(-\mathrm{C}_{3}\right) ; \quad 46.9\left(-\mathrm{C}_{5}\right) ; 25.7\left(-\mathrm{C}_{6}\right) ; 20.9 ;$ 15.6. LC-MS $(\mathrm{m} / \mathrm{z}): 699.3\left[\mathrm{MH}^{+}\right]$. Found, \%: C 68.23; H 5.33;
$\mathrm{N}$ 7.46. $\mathrm{C}_{42} \mathrm{H}_{40} \mathrm{Cl}_{2} \mathrm{O}_{4} \mathrm{~N}_{4}$. Calculated, \%: C 68.57; H 5.48; N 7.62 .

1,4-Bis(1-(6-acetyl-2H-1,4-benzoxazine-3(4H)one)benzimidazolium-3-yl)butane dichloride (2b). Yield $1.53 \mathrm{~g}, 69 \%$, mp $270{ }^{\circ} \mathrm{C}$. IR spectrum, $\mathrm{v}, \mathrm{cm}^{-1}$ : $3376(\mathrm{NH}) ; 1674(\mathrm{CO}) ; 1601(\mathrm{C}=\mathrm{N}) .{ }^{1} \mathrm{H}-\mathrm{NMR}(600$ $\left.\mathrm{MHz}, \mathrm{DMSO}-\mathrm{d}_{6}\right), \delta$, ppm; 11.15(s, $\left.1 \mathrm{H}, \mathrm{H}_{1}\right) ; 10.11(\mathrm{~s}$, $\left.1 \mathrm{H}, \mathrm{H}_{6}\right) ; 8.20-7.18\left(\mathrm{~m}, 7 \mathrm{H}, \mathrm{H}_{\mathrm{Ar}}\right) ; 6.43\left(\mathrm{~s}, 2 \mathrm{H}, \mathrm{H}_{5}\right)$; 4.75(s, 4H, $\mathrm{H}_{3}$ and $\left.\mathrm{H}_{7}\right) ; 2.08\left(\mathrm{~s}, 2 \mathrm{H}, \mathrm{H}_{8}\right)$. ${ }^{13} \mathrm{C}-\mathrm{NMR}$ $\left(150 \mathrm{MHz}, \mathrm{DMSO}-\mathrm{d}_{6}\right), \delta$, ppm: $190.0\left(-\mathrm{C}_{4}\right) ; 164.4$ $\left(-\mathrm{C}_{2}\right) ; 148.7 ; 144.0\left(-\mathrm{C}_{6}\right) ; 132.5 ; 131.1 ; 128.5 ; 128.1$; $127.3 ; 127.1 ; 125.3 ; 116.8 ; 115.9 ; 114.5 ; 114.3$; 67.3(-C 5$) ; 53.3\left(-\mathrm{C}_{3}\right) ; 46.6\left(-\mathrm{C}_{7}\right) ; 25.9\left(-\mathrm{C}_{8}\right)$. Found, \%: C 61.34; H 4.43; N 11.47. LC-MS (m/z):705.2 $\left[\mathrm{MH}^{+}\right] . \quad \mathrm{C}_{38} \mathrm{H}_{34} \mathrm{Cl}_{2} \mathrm{O}_{6} \mathrm{~N}_{6}$. Calculated, \%: C 61.54; $\mathrm{H} 4.62$; N 11.33.

General procedure for transfer hydrogenation reaction (General Method). In a typical experiment, $0.01 \mathrm{mmol}(6.1 \mathrm{mg})$ of [(pcymene) $\left.\mathrm{RuCl}_{2}\right]_{2}$ with $0.02 \mathrm{mmol}$ of benzimidazolium or bis(benzimidazolium) chlorides, $10 \mathrm{mmol}$ of $p$-substituted acetophenone derivatives and $5 \mathrm{mmol}(280 \mathrm{mg})$ of $\mathrm{KOH}$ were heated at $80{ }^{\circ} \mathrm{C}$ for a period of $180 \mathrm{~min}$ in 2-propanol $(6 \mathrm{~mL})$ as a hydrogen source. After the desired reaction time, the sample was diluted with diethyl ether $(2 \mathrm{~mL})$ and filtered from a mini-column. The purity of the compounds was checked by GC. The yields obtained were related to the residual unreacted acetophenone. The reactions were conducted at a $(\mathrm{S} / \mathrm{C} / \mathrm{base})$ molar ratio of 10: 0.02: 1

\section{Carbonic anhydrase inhibiton}

Preparation of hemolysate and purification

\section{from blood red cells}

Blood samples $(25 \mathrm{~mL})$ were taken from healthy volunteers. They were anticoagulated with acidcitrate-dextrose, centrifuged at $2000 \mathrm{~g}$ for $20 \mathrm{~min}$ at $4{ }^{\circ} \mathrm{C}$ and the supernatant was removed. The packed erythrocytes were washed three times with $0.9 \%$ $\mathrm{NaCl}$ and then hemolyzed in cold water. The ghosts and any intact cells were removed by centrifugation at $2000 \mathrm{~g}$ for $25 \mathrm{~min}$ at $4^{\circ} \mathrm{C}$, and the $\mathrm{pH}$ of the hemolysate was adjusted to $\mathrm{pH} 8.5$ with solid Trisbase. The $25 \mathrm{~mL}$ hemolysate was applied to an affinity column containing L-tyrosine-sulfonamideSepharose- $4 \mathrm{~B}^{51}$ equilibrated with $25 \mathrm{mM}$ Tris- $\mathrm{HCl} /$ $0.1 \mathrm{M} \mathrm{Na}_{2} \mathrm{SO}_{4}(\mathrm{pH} 8.5)$. The affinity gel was washed with $50 \mathrm{~mL}$ of $25 \mathrm{mM}$ Tris- $\mathrm{HCl} / 22 \mathrm{mM} \mathrm{Na}_{2} \mathrm{SO}_{4}(\mathrm{pH}$ 8.5). The human $\mathrm{CA}$ (hCA) isozymes were then eluted with $0.1 \mathrm{M} \mathrm{NaCl} / 25 \mathrm{mM} \mathrm{Na}_{2} \mathrm{HPO}_{4}(\mathrm{pH} 6.3$ ) and $0.1 \mathrm{M} \mathrm{CH}_{3} \mathrm{COONa} / 0.5 \mathrm{M} \mathrm{NaClO}_{4}$ (pH 5.6), which recovered hCA-I and hCA-II respectively. Fractions of $3 \mathrm{~mL}$ were collected and their absorbance measured at $280 \mathrm{~nm}$.

\section{Hydratase activity assay}

CA activity was measured by the Maren method which is based on determination of the time required for the $\mathrm{pH}$ to decrease from 10.0 to 7.4 due to $\mathrm{CO}_{2}$ hydration ${ }^{52}$. The assay solution was $0.5 \mathrm{M} \mathrm{Na}_{2} \mathrm{CO}_{3} /$ $0.1 \mathrm{M} \mathrm{NaHCO}_{3}(\mathrm{pH} \mathrm{10.0)}$ and phenol red was added 
as the $\mathrm{pH}$ indicator. $\mathrm{CO}_{2}$-hydratase activity (enzyme units (EU)) was calculated by using the equation $t_{0^{-}}$ $t_{c} / t_{c}$ where $t_{0}$ and $t_{c}$ are the times for $\mathrm{pH}$ change of the nonenzymatic and the enzymatic reactions, respectively.

\section{Esterase activity assay}

Carbonic anhydrase activity was assayed by following the change in absorbance at $348 \mathrm{~nm}$ of 4nitrophenyl-acetate (NPA) to 4-nitrophenylate ion over a period of $3 \mathrm{~min}$ at $25^{\circ} \mathrm{C}$ using a spectrophotometer (HACH LANGE DV 6000 UVVIS) according to the method described in the literature $^{53}$. The enzymatic reaction, in a total volume of $3.0 \mathrm{~mL}$, contained $1.4 \mathrm{~mL}$ of $0.05 \mathrm{M}$ Tris$\mathrm{SO}_{4}$ buffer $(\mathrm{pH} \quad 7.4), 1 \mathrm{~mL}$ of $3 \mathrm{mM} \quad 4-$ nitrophenylacetate, $0.5 \mathrm{~mL} \mathrm{H}_{2} \mathrm{O}$ and $0.1 \mathrm{~mL}$ enzyme solution. A reference measurement was obtained by preparing the same cuvette without enzyme solution. The inhibitory effects of the synthesized compunds were examined. All compounds were tested in triplicate at each concentration used. Different concentrations of the compounds were used.

\section{In vitro inhibition studies}

For the inhibition studies of the synthesized compounds, different concentrations of compounds were added to the enzyme. The activity percentage values of $\mathrm{CA}$ for different concentrations of each coumarin and benzoxazinone derivative were determined by regression analysis using Microsoft Office 2000 Excel. CA enzyme activity without compounds 1-2b solution was accepted as $100 \%$ activity.

\section{References}

1- H. A. Barker, R. D. Smyth, H. Weissbach, J. I. Toohey, B. E. Volcani, J. Biol. Chem., 1960, 235, 480-488.

2- K. Kubo, Y. Inada, Y. Kahara, Y. Sugiura, M. Ojima; K. Itoh, Y. Furukawa, K. Nishikawa, T. Naka, J. Med. Chem., 1993, 36, 1772-1784.

3- K. C. S. Achar, K. M. Hosamani, H. R. Seethaaramareddy, Eur. J. Med. Chem., 2010, 45, 2048-2054

4- K. G. Desai, K. R. Desai, Bioorg. Med. Chem., 2006, 14, 8271-8279.

5- $\quad$ S. K. Kotouskaya, Z. M. Baskakova, V. U. Chararushin, O. N. Chupakhin, E. F. Belanov, N. I. Bormotov, S. M. Balakhin, O. A. Serova, Pharm. Chem. J., 2005, 39, 574-578.

6- $\quad$ E. R. Cole, G. Crank, S. Sheikh J. Agr. Food Chem., 1974, 22, 918.

7- $\quad$ H. M. Refaat, Eur. J. Med. Chem., 2010, 45, 2949-2956.

8- J. M. Travins, R. C. Bernatas, D. H. Kaufman, E. Quiret, P. Nambi, I. Feingold, C. Huselton, A. Wilhelmsson, A. GoosNilsson, J. Wrobel, Bioorg. Med. Chem. Lett., 2010, 20, 526-530.
9- N. H. Havel, H. Nar, H. Priepke, U. Ries, J. M. Stanssen, W. Wienen, J. Med. Chem., 2002, 45, 1757-1766.

10- S. Cekirdek, S. Yasar, I. Ozdemir, Appl. Organomet. Chem., 2014, 28, 423-431.

11- S. Demir, M. Yigit, I. Ozdemir, J. Organomet. Chem., 2013, 732, 21-26.

12- D. Kumar, A. P. Prakasham, L. P. Bheeter, J. B. Sortais, M. Gangwar, T. Roisnel, A. C. Kalita, C. Darcel, P. Ghosh, J. Organomet. Chem., 2014, 762, 81-87.

13- H. Turkmen, S. Denizaltı, I. Ozdemir, E. Cetinkaya, B.Cetinkaya, J. Organomet. Chem., 2008, 693, 425-434.

14- N. Gurbuz, S. Demir, I. Ozdemir, B. Cetinkaya, C. Bruneau, Tetrahedron, 2010, 66, 1346-1351.

15- A. Slamani, S. Demir, I. Ozdemir, Catal. Commun., 2012, 29, 141-144.

16- R. Noyori, S. Hashiguchi, Acc. of Chem. Res., 1997, 30, 97-102.

17- I. Yamada, R. Noyori, Org. Lett., 2000, 2, 3425-3427.

18- S. Dayan, F. Arslan, N. K. Ozpozan, Appl. Catal. B:Environmental, 2015, 164, 305-315.

19- G. S. Clark, Perfumer and Flavonist, 1995, 20, 23-24.

20- B. G. Lake, Food and Chem Toxic., 1997, 37, 423-453.

21- P. Anand, B. Singh, M. Singh, Bioorg. Med. Chem., 2012, 20, 1175-1180.

22- D. Yu, M. Suzuki, L. Xie, S. L. MorrisNatschke, K. H. Lee, Med. Res. Rev., 2003, 23, 322-345.

23- A. Maresca, C. Temperini, H. Vu, N. B. Pham, S. A. Poulsen, A. Scozzafava, R. J. Quinn, C. T. Supuran, J. Am. Chem. Soc., 2009, 131, 3057-3062.

24- A. Maresca, C. Temperini, L. Pochet, B. Masareel, A. Scozzafava, C. T. Supuran, J. Med. Chem., 2010, 53, 335-344.

25- M. G. Nair, D. C. Salter, R. L. Kisliuk, Y. Gaumont, G. North, J. Med. Chem., 1983, 26, 1164-1168.

26- Y. Katsura, S. Nishino, H. Takasugi, Chem. Pharm. Bull., 1991, 39, 2937-2943.

27- M. Kajino, Y. Shibouta, K. Nishikawa, K. Megura, Chem. Pharm. Bull., 1991, 38, 2896-2905.

28- S. Wahidulla, J. J. Bhattaeharje, J. Indian Inst. Sci., 2001, 81, 485-490.

29- L. Fang, H. Zuo, Z. B. Li, X. Y. He, L. Y. Wang, X. Tian, B. X. Zhao, J. Y. Miao, D. S. Shin, Med. Chem. Res., 2011, 20, 670-677.

30- X. Li, N. Liu, H. Zhang, S. E. Knudson, R. A. Slayden, P. J. Tonge, Bioorg. Med. Chem. Lett., 2010, 20, 6306-6309.

31- R. Fringuelli, N. Giacche, L. Milanese, E. Cenci, F. Macchiarulo, Bioorg. Med. Chem., 2009, 17, 3838-3846. 
32- C. F. Turk, J. Krapcho, I. M. Miche, I. Weinryb, J. Med. Chem., 1997, 20, 730732.

33- A. Thiry, J. M. Dogne, C. T. Supuran, B. Masareel, Curr. Top Med. Chem., 2007, 7, 855-864.

34- C. T. Supuran, Nat. Rev. Drug Discov., 2008, 7, 168-181.

35- A. Thiry, J. M. Dagne, B. Masareel, C. T. Supuran, Trends Pharmacol. Sci., 2006, 27, 566-573.

36- J. M. McKiernan, R. Buttyan, N. H. Bander, M. D. Stifelman, A. E. Katz, M. W. Chen, C. A. Olsson, I. S. Sauchuk, Cancer. Res., 1997, 57, 2362-2365.

37- A. Scozzafava, A. Mastrolorenzo, C. T. Supuran, Expert Opin. Ther. Pat., 2006, 16, 1627-1644.

38- C. T. Supuran, A. Scozzafava, A. Casini, Med. Res. Rev., 2003, 23, 146-189.

39- K. S. Smith, J. G. Ferry, FEMS Microbial Rev., 2000, 24, 335-366.

40- T. Stams and D. W. Christianson, X-ray crystallographic studies of mammalian carbonic anhydrase isozymes. In: Chegwidden WR, Carter ND, Edwards YH, eds. X-ray crystallographic studies of mammalian carbonic anhydrase isozymes. The Carbonic Anhydrases: New Horizons. Boston: Birkhauser Verlag, 2000, 159.

41- S. Pastorekova, S. Parkilla, J. Pastorek, C. T. Supuran, J. Enzyme Inhib. Med. Chem., 2004, 19, 199-229.

42- I. Nishimori, T. Minakuchi, S. Onishi, D. Vullo, A. Cecchi, A. Scozzafava, C. T.
Supuran, Bioorg. Med. Chem., 2007, 15, 7229-7236.

43- D. Vullo, M. Franchi, E. Gallori, A. Scozzafava, C. T. Supuran, J. Med. Chem., 2004, 47, 1272-1279.

44- I. Nishimori, D. Vullo, A. Innocenti, A. Scozzafava, A. Mastrolorenzo, C. T. Supuran, J. Med. Chem., 2005, 48, 7860-7866.

45- I. Nishimori, T. Minakuchi, S. Onishi, D. Vullo, A. Scozzafava, C. T. Supuran, J. Med. Chem., 2007, 50, 381-388.

46- D. Vullo, J. Vaipio, A. Innocenti, C. Rivera, H. Ranki, A. Scozzafava, C. T. Supuran, Bioorg. Med. Chem. Lett., 2005, 15, 971-976.

47- D. Vullo, A. Innocenti, I. Nishimori, J. Pastorek, A. Scozzafava, S. Pastorekova, C. T. Supuran, Bioorg. Med. Chem. Lett., 2005, 15, 963-969.

48- M. S. Frasinyuk, V. I. Vinogradova, S. P. Bondarenko, V. P. Khilya, Chem. Nat. Comp., 2007, 43, 176-180.

49- N. Korkmaz, O. A. Obaidi, M. Senturk, D. Astley, D. Ekinci, C. T. Supuran, J. Enzyme Inhib. Med. Chem., 2015, 30, 75-80.

50- I. Ozdemir, N. Sahin, S. Demir, B. Cetinkaya, J. Molec. Catal. A, 2005, 234, 181-185.

51- O. Arslan, B. Nalbantoglu, N. Demir, H. Ozdemir, O. I. Kufrevioglu, Turk. J. Med. Sci., 1996, 26, 163-166.

52- T. H. Maren, J. Pharm. Exp. Ther., 1960, 130, 2629-2634.

53- J. A. Verpoorte, S. Mehta, J.T. Edsall, J. Biol. Chem., 1967, 242, 4221-4229. 